\title{
Preparation of Cathode-Anode Integrated Ceramic Filler and Application in a Coupled ME-EGSB-SBR System for Chlortetracycline Industrial Wastewater Systematic Treatment
}

\author{
Yuanfeng Qi, ${ }^{1,2}$ Suqing Wu, ${ }^{1}$ Fei Xi, ${ }^{2}$ Shengbing He, ${ }^{1}$ Chunzhen Fan, ${ }^{1}$ Bibo Dai, ${ }^{2}$ \\ Jungchen Huang, ${ }^{1}$ Meng Meng, ${ }^{2}$ Xiangguo $\mathrm{Zhu},{ }^{2,3}$ and Lei Wang ${ }^{2,4}$ \\ ${ }^{1}$ School of Environmental Science and Engineering, Shanghai Jiaotong University, Shanghai 200240, China \\ ${ }^{2}$ Shandong ATK Environmental Engineering Company Limited, Jinan 250101, China \\ ${ }^{3}$ Shandong Kenli Petrochemical Group, Dongying 257500, China \\ ${ }^{4}$ Shandong Wonfull Petrochemical Group Co., Ltd., Zibo 256410, China \\ Correspondence should be addressed to Shengbing He; shengbing_he@163.com
}

Received 28 June 2016; Revised 6 September 2016; Accepted 20 September 2016

Academic Editor: Manuel A. R. Rodrigo

Copyright (C) 2016 Yuanfeng Qi et al. This is an open access article distributed under the Creative Commons Attribution License, which permits unrestricted use, distribution, and reproduction in any medium, provided the original work is properly cited.

\begin{abstract}
Chlortetracycline (CTC) contamination of aquatic systems has seriously threatened the environmental and human health throughout the world. Conventional biological treatments could not effectively treat the CTC industrial wastewater and few studies have been focused on the wastewater systematic treatment. Firstly, $40.0 \mathrm{wt} \%$ of clay, $30.0 \mathrm{wt} \%$ of dewatered sewage sludge (DSS), and $30.0 \mathrm{wt} \%$ of scrap iron (SI) were added to sinter the new media (cathode-anode integrated ceramic filler, CAICF). Subsequently, the nontoxic CAICF with rough surface and porous interior packed into ME reactor, severing as a pretreatment step, was effective in removing CTC residue and improving the wastewater biodegradability. Secondly, expanded granular sludge bed (EGSB) and sequencing batch reactor (SBR), serving as the secondary biological treatment, were mainly focusing on chemical oxygen demand (COD) and ammonia nitrogen $\left(\mathrm{NH}_{3}-\mathrm{N}\right)$ removal. The coupled ME-EGSB-SBR system removed about $98.0 \%$ of CODcr and $95.0 \%$ of $\mathrm{NH}_{3}-\mathrm{N}$ and the final effluent met the national discharged standard (C standard of CJ 343-2010, China). Therefore, the CTC industrial wastewater could be effectively treated by the coupled ME-EGSB-SBR system, which has significant implications for a cost-efficient system in CTC industrial systematic treatment and solid wastes (DSS and SI) treatment.
\end{abstract}

\section{Introduction}

As a biological wastewater treatment process, activated sludge technology has been widely used in municipal and industrial wastewater treatment. However, large amounts of excess sludge, generated as by-product during the process, usually contain organic and mineral components [1] and pathogenic and toxic substances $[2,3]$, which has hindered application of activated sludge process. Generally, disposal of excess sludge might account for more than $60 \%$ of the total operating expenditure in a wastewater treatment plant [4]. Various methods have been applied in excess sludge treatment, including incineration, land application, land filling, road surfacing, and conversion to fertilizer [5]. Although these studies achieved some desired effect in treating excess sludge, these methods were uneconomical, unsafe, or insanitary. Therefore, eco-friendly and economical methods for safe handling, disposal, and recycling of excess sludge are of great significance.

As a kind of solid waste, large quantity of scrap iron might be generated and discarded by machinery plants, resulting in waste of resources. In recent years, scrap iron has been utilized in many manners, mainly including hexavalent chromium reduction [6], sulfur dioxide removal [7], azo dyes wastewater pretreatment [8], and antibiotics residue removal [9]. These methods are insufficient for scrap iron reusing; therefore, more economical and effective methods are essential for recycling scrap iron.

In the past several decades, excess sewage sludge and scrap iron have been utilized to prepare ceramics, which have 
been widely used in construction industry, chemical industry, metallurgy, agriculture, and environmental protection [10], resulting in reusing these solid wastes and reducing clay consumption during ceramics production.

CTC, as a broad-spectrum antibiotic, has been widely used in disease control and animal growth [11, 12]. Large amounts of wastewater are generated from fermentation process during CTC production, mainly containing fermentation medium residue, mycelium, and various complicated metabolites (carbohydrates, proteins, organic acids, etc.). In addition, CTC extraction process also generates some wastewater, mainly containing organic solvent, acid, alkali, and antibiotic residue. Therefore, CTC industrial wastewater is difficultly degraded by biological methods and it will accumulate constantly [13]. So far, lots of methods have been utilized to treat the CTC industrial wastewater, including photodegradation [14-17], advanced oxidation/reduction [18, 19], manganese oxidation [20], and sorption [21-24]. Although these studies obtained some desired effect, very few of them could be applied in practical project due to their rigorous reaction conditions and expensive operating cost. Consequently, it is important to develop economical and easily applicable methods for real CTC industrial wastewater treatment.

In our previous study [25], a coupled ME-EGSB-A/O system was utilized for oxytetracycline (OTC) production wastewater treatment. In this study, a similar coupled system (ME-EGSB-SBR) was applied to treat CTC production wastewater. Although similar treatment system was used in the two studies, different fillers were prepared and applied in $\mathrm{ME}$ reactor, cathode fillers (CCF) and anode fillers (ACF) in different particle bodies were sintered separately in the previous study while cathode and anode fillers were incorporated in the same particle body, and the incorporate fillers (CAICF) were prepared in the present study, which could simplify preparation process of the fillers and enhance the treatment efficiency of the ME reactor. Therefore, in this study, a coupled ME-EGSB-SBR system was utilized for CTC industrial wastewater treatment.

Firstly, new media (CAICF) were prepared from DSS, SI, and clay and subsequently applied as fillers for ME reactor. Microelectrolysis technology, developed on the basis of electrochemistry, was first applied in Europe during the 1960s [26]. Its principles are very similar to electrochemical methods, and the electrons are supplied from the galvanic corrosion of many microscale sacrificial anodes without external power supply. Numerous microscopic galvanic cells are formed between the iron and carbon particles when contacted with wastewater (electrolyte solution). The half-cell reactions can be represented as follows [27, 28]:

$$
\begin{aligned}
& \text { Anode (oxidation) : } 2 \mathrm{Fe} \longrightarrow 2 \mathrm{Fe}^{2+}+4 \mathrm{e}^{-}, \\
& \qquad E^{\theta}\left(\mathrm{Fe}^{2+} / \mathrm{Fe}\right)=-0.44 \mathrm{~V} \\
& \text { Cathode (reduction) : Acidic } 2 \mathrm{H}^{+}+2 \mathrm{e}^{-} \longrightarrow \mathrm{H}_{2} \uparrow, \\
& \qquad E^{\theta}\left(\mathrm{H}^{+} / \mathrm{H}_{2}\right)=0 \mathrm{~V} \\
& \mathrm{O}_{2}+4 \mathrm{H}^{+}+4 \mathrm{e}^{-} \longrightarrow 2 \mathrm{H}_{2} \mathrm{O}, \quad E^{\theta}\left(\mathrm{O}_{2} / \mathrm{H}_{2} \mathrm{O}\right)=+1.23 \mathrm{~V}
\end{aligned}
$$

$$
\begin{aligned}
& \text { Neutral to alkaline: } \mathrm{O}_{2}+2 \mathrm{H}_{2} \mathrm{O}+4 \mathrm{e}^{-} \longrightarrow 4 \mathrm{OH}^{-} \\
& \qquad E^{\theta}\left(\mathrm{O}_{2} / \mathrm{OH}^{-}\right)=+0.40 \mathrm{~V} .
\end{aligned}
$$

In recent years, $\mathrm{ME}$ has been widely used to treat refractory wastewaters, including landfill leachate [29], pharmaceutical wastewater [30], palm oil mill wastewater [31], ionic liquids wastewater [32], coking wastewater [33], and dyeing wastewater $[26,34]$. In this research, ME was used as the wastewater pretreatment, mainly focusing on CTC residue removal and improvement of the wastewater biodegradability, which could facilitate subsequent biological treatments.

Secondly, EGSB followed by SBR was utilized as the secondary biological treatment for the CTC wastewater. EGSB, as a representative kind of anaerobic bioreactors, was mainly based on the mechanisms about anaerobic biological degradation of organic contaminants. When influent wastewater flowed through the anaerobic bioreactor, the contained organic contaminants were biologically degraded by the anaerobic microorganisms in granule sludge with COD removal and methane generation. Therefore, EGSB has been applied to disposal of high concentrated organic wastewaters, including brewing industry wastewater [35, 36], starch extracting wastewater [37], trichloroethylene-contaminated wastewater [38], and industrial oil wastewater [39]. SBR systems have been remarkably employed in industrial and municipal wastewater treatment for many years [40], such as wastewater containing p-nitrophenol [41], dairy effluents [42], and soybean-processing wastewater [43]. The secondary treatment was mainly used to remove majority of CODcr and $\mathrm{NH}_{3}-\mathrm{N}$ in the wastewater.

\section{Materials and Methods}

2.1. Materials. DSS, SI, and clay, utilized as raw materials to prepare CAICF, were obtained from Jinan wastewater treatment plant, a machinery plant in Jinan city (Shandong Province, China), and a brickyard in Zibo city (Shandong Province, China), respectively. The components of DSS and clay were shown in Table 1 and the raw materials were dried at $105^{\circ} \mathrm{C}$ for $4 \mathrm{~h}$, crushed in a ball mill, sieved through a $0.154 \mathrm{~mm}$ mesh, and then stored in polyethylene vessels to avoid humidification before utilization.

The utilized CTC industrial wastewater, obtained from a CTC manufacturing factory in Hohhot city (Inner Mongolia Autonomous Region, China), was mainly generated from separation and extraction processes of CTC, equipment rinsing process. The main water quality of the raw wastewater and the national discharged standard (wastewater quality standards for discharge to municipal sewers, C standard of CJ 343-2010, China) are shown in Table 2, revealing that the wastewater quality was not stable and all indexes of the wastewater did not meet the national discharged standard. In the wastewater treatment plant of this enterprise, the utilized wastewater treatment system mainly contained flocculation and precipitation, upflow anaerobic sludge blanket (UASB) (two anaerobic reactors were connected in series), cyclic activated sludge system (CASS), anoxic/oxic activated sludge 
TABLE 1: Chemical components of clay and DSS (wt\%).

\begin{tabular}{lccccccccc}
\hline & $\mathrm{SiO}_{2}$ & $\mathrm{Al}_{2} \mathrm{O}_{3}$ & $\mathrm{Fe}_{2} \mathrm{O}_{3}$ & $\mathrm{CaO}$ & $\mathrm{K}_{2} \mathrm{O}$ & $\mathrm{Na}_{2} \mathrm{O}$ & Sulfate & Phosphate & Others \\
\hline DSS & 29.94 & 18.50 & 9.48 & 21.42 & 1.78 & - & 9.43 & 5.37 & 4.08 \\
Clay & 63.28 & 18.75 & 7.72 & 1.23 & 2.14 & 2.07 & - & - & 4.81 \\
\hline
\end{tabular}

TABLE 2: The components of the raw CTC industrial wastewater and the national standard.

\begin{tabular}{lccr}
\hline Indexes & Unit & Concentration range & CJ 343-2010, C standard \\
\hline CODcr & $\mathrm{mg} \mathrm{L}^{-1}$ & $10474-16855$ & $\leq 300$ \\
$\mathrm{NH}_{3}-\mathrm{N}$ & $\mathrm{mg} \mathrm{L}^{-1}$ & $358.5-840.2$ & $\leq 25$ \\
Suspended solid (SS) & $\mathrm{mg} \mathrm{L}^{-1}$ & $847.5-1049$ & $\leq 300$ \\
Chroma & - & $210.5-332.3$ & $\leq 60$ \\
$\mathrm{pH}$ & - & $4.60-6.52$ & $6.50-9.50$ \\
$\mathrm{CTC}$ residue & $\mathrm{mg} \mathrm{L}^{-1}$ & $72.8-102.6$ & - \\
$\mathrm{BOD}_{5}$ & $\mathrm{mg} \mathrm{L}^{-1}$ & $1124.3-1532.5$ & $\leq 150$ \\
\hline
\end{tabular}

process (A/O), and Fenton oxidation. However, this complicated system had several problems: (1) the two anaerobic reactors could not operate stably and granule sludge in the reactors disintegrated greatly and must be renewed every three months; (2) the system required high operating cost, mainly resulting from the renewal of granule sludge and operation of the Fenton process; (3) the final effluent of the system (CODcr of $586-673 \mathrm{mg} \mathrm{L}^{-1}, \mathrm{NH}_{3}-\mathrm{N}$ of $21.5-$ $26.8 \mathrm{mg} \mathrm{L}^{-1}$, SS of $97.5-113.8 \mathrm{mg} \mathrm{L}^{-1}$, chroma of $200-300$ ) did not meet the discharged national standard (CODcr $\leq$ $300 \mathrm{mg} \mathrm{L}^{-1}, \mathrm{NH}_{3}-\mathrm{N} \leq 25 \mathrm{mg} \mathrm{L}^{-1}$, $\mathrm{SS} \leq 300 \mathrm{mg} \mathrm{L}^{-1}$, chroma $\leq 60)$. Therefore, it is necessary to improve the system or develop new system for the CTC wastewater treatment.

According to our previous study [28], CAICF was prepared according to the following three steps.

Step 1 (dosing, mixing, pelleting, screening, and drying). Clay, DSS, and SI $(4: 3: 3, \mathrm{w} / \mathrm{w} / \mathrm{w})$ were completely mixed and poured into a pelletizer (DZ-20) to produce raw pellets (about $7.00 \mathrm{wt} \%$ of water was added). Then, the raw pellets were sieved (the diameters were $5.0-6.0 \mathrm{~mm}$ ) and stored in draught cupboard at room temperature $\left(22^{\circ} \mathrm{C}\right)$ for about $24 \mathrm{~h}$ before thermal treatment.

Step 2 (sintering treatment). The dried raw pellets were rapidly transferred into electric tube rotary furnace (KSY-4D16) and sintered at $400^{\circ} \mathrm{C}$ for $20 \mathrm{~min}$ in anoxic conditions.

Step 3 (cooling treatment). After the sintering treatment, the pellets were transferred to draught cupboard until they cooled down to room temperature $\left(22^{\circ} \mathrm{C}\right)$.

\subsection{Starting and Operating of the Wastewater Treatment} System. In this study, a coupled ME-EGSB-SBR system was utilized for the CTC industrial wastewater treatment. A pilotscale experiment was set up for the wastewater treatment as shown Figure 1; all units were made of stainless steel to prevent possible corrosion caused by the wastewater and to eliminate potential photodegradation by the light.

Firstly, flocculation and precipitation processes were used to remove SS in the raw wastewater and prevent blockage of the ME reactor. Then the wastewater was introduced into the regulating reservoir 1 (cylinder, $1.0 \mathrm{~m}$ in diameter and $1.5 \mathrm{~m}$ tall) to adjust $\mathrm{pH}$ of the wastewater by adding hydrochloric acid $(\mathrm{HCl})$ solution. Seven initial $\mathrm{pH}$ values $(1.0,2.0,3.0,4.0$, 5.0, 6.0, and 7.0) and eight hydraulic retention times (HRTs, $1.0,2.0,3.0,4.0,5.0,6.0,7.0$, and $8.0 \mathrm{~h}$ ) were selected to determine the optimum conditions of $\mathrm{ME}$ reactor according to the removal rate of CTC residue and CODcr. $30 \mathrm{~cm}$ of cobble stone was packed as supporting layer at the bottom of $\mathrm{ME}$ reactor (cylinder, $1.0 \mathrm{~m}$ diameter and $2.0 \mathrm{~m}$ height) with $1.0 \mathrm{~m}$ of CAICF as media layer on the top, leaving a bottom space of $20 \mathrm{~cm}$ for water and air distribution and headspace of $30 \mathrm{~cm}$ to retain fillers during backwashing. The wastewater was pumped into the reactor through the inlet at the bottom and discharged to the regulating reservoir 2 (cylinder, $1.0 \mathrm{~m}$ in diameter and $1.5 \mathrm{~m}$ tall) from the upper outlet.

Secondly, calcium hydroxide $\left(\mathrm{Ca}(\mathrm{OH})_{2}\right)$ solution was added to adjust and keep $\mathrm{pH}$ of the wastewater to about 7.0 before being introduced into EGSB tank. At start-up stage, the up-flow EGSB tank (cylinder, $1.2 \mathrm{~m}$ in diameter and $5.0 \mathrm{~m}$ tall) with an effective volume of approximately $3.96 \mathrm{~m}^{3}$ was inoculated with granule sludge (approximately $1.2 \mathrm{~m}^{3}$ ) from a local starch factory at a concentration of approximately $15.9 \mathrm{~g} \mathrm{VSS} \mathrm{L}^{-1}$, and the starting organic loading rate (OLR) was about $0.5 \mathrm{~kg} \mathrm{~m}^{-3} \mathrm{~d}^{-1}$. During the operation, OLR was increased gradually until the optimum OLR was determined by the CODcr removal efficiency. Other conditions including temperature and $\mathrm{pH}$ were kept at about $35.0^{\circ} \mathrm{C}$ and 7.0 , respectively. The effluent was discharged into sludge precipitation reservoir (cylinder, $1.0 \mathrm{~m}$ in diameter and $1.5 \mathrm{~m}$ tall) and excess sludge was returned to the EGSB tank via a reflux sludge pump.

Thirdly, the supernatant of sludge precipitating reservoir was pumped into SBR reactor (cuboid, $1.2 \mathrm{~m} \times 0.6 \mathrm{~m} \times$ $0.65 \mathrm{~m}$ ) with an effective volume of approximately $0.43 \mathrm{~m}^{3}$. At the start-up stage, the reactor was inoculated with activated sludge obtained from the same starch factory at a solids concentration of approximately $5.4 \mathrm{~g} \mathrm{MLSS} \mathrm{L}^{-1}$. During the operation, the time for influent feeding, aerating, precipitating, and effluent discharging was $1.0 \mathrm{~h}, 4.0 \mathrm{~h}, 2.0 \mathrm{~h}$, and $1.0 \mathrm{~h}$, respectively. Additionally, temperature and $\mathrm{pH}$ of the 


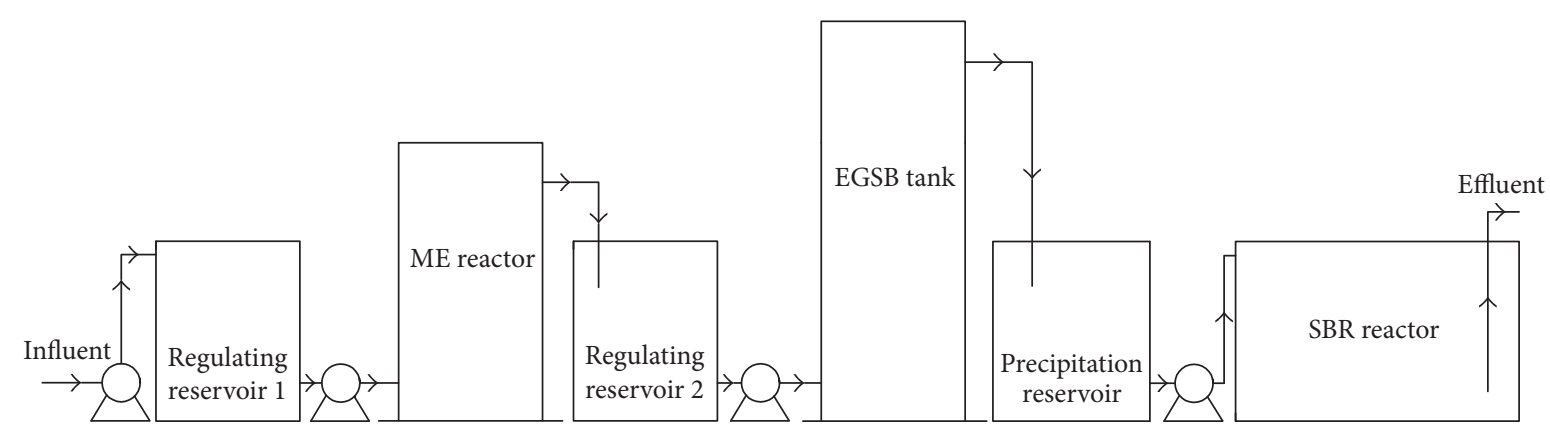

FIgURE 1: The treatment system of CTC wastewater.

wastewater were controlled at about $30.0^{\circ} \mathrm{C}$ and 7.0 by adding $\mathrm{NaHCO}_{3}$ solution. Finally, the effluent was discharged from the wastewater treatment system into urban sewage pipe network.

All pumping and mixing cycles in the system were operated via four metering pumps (JsbasenGM500/0.3, Beijing, China) and a sludge pump (LanshenQJB-W4, Nanjing, China). The dissolved oxygen (DO) concentration in the SBR reactor was controlled at $2.0-4.0 \mathrm{mg} \mathrm{L}^{-1}$ using a Roots blower (FengyuanFRMG350, Shandong, China).

\subsection{Analytical Methods}

2.3.1. Properties of CAICF. According to our previous study [44], water absorption and bulk density were measured by the national standard (lightweight aggregates and the test methods-part 2, test methods for lightweight aggregate, GB/T 17431.2-2010, China) and grain density was calculated according to Archimedes' principle. The above-mentioned physical properties were calculated as follows:

$$
\begin{aligned}
\text { Bulk density } & =\frac{\text { mass of ceramic bodies }}{\text { bulk volume of ceramic bodies } \mathrm{kg} \cdot \mathrm{m}^{-3}} \\
\text { Grain density } & =\frac{\text { mass of ceramic bodies }}{\text { volume of ceramic bodies } \mathrm{kg} \cdot \mathrm{m}^{-3}} \\
\text { Water absorption } & =\frac{1 \mathrm{~h} \text { saturated mass of ceramic bodies }- \text { mass dry of ceramic bodies }}{\text { mass of dry ceramic bodies }} \times 100 \%
\end{aligned}
$$

Structural and morphological analysis was conducted by scanning electron microscopy (SEM, Hitachi S-520, Japan) both in the surface and in the cross section (Au coated).

$1000.00 \mathrm{~g}$ of CAICF was soaked into $1.00 \mathrm{~L}$ of $\mathrm{HCl}$ $\left(0.20 \mathrm{~mol} \mathrm{~L}^{-1}\right)$ for $24 \mathrm{~h} .1 .00 \mathrm{~mL}$ of leach solution obtained from the supernatant was collected for leaching test of the toxic metal elements. Toxic metal concentrations $(\mathrm{Cu}, \mathrm{Zn}, \mathrm{Pb}$, $\mathrm{Cr}, \mathrm{Cd}, \mathrm{Hg}, \mathrm{Ba}, \mathrm{Ni}$, and As) of $1000.00 \mathrm{~g}$ of CAICF were determined by ICP-AES (IRIS Intrepid II XSP equipment, Thermo Electron, USA) and were compared with national standard (identification standards for hazardous wastes, identification for extraction toxicity, GB 5085.3-2007, China).

2.3.2. Characterization of Wastewater. CODcr, $\mathrm{NH}_{3}-\mathrm{N}, \mathrm{SS}$, $\mathrm{BOD}_{5}$, chroma, and $\mathrm{pH}$ of the wastewater were measured according to national standard methods (State Environmental Protection Administration of China, Monitoring and Analysis Methods of Water and Wastewater, fourth ed., China Environmental Science Press, Beijing), and volatile fatty acid (VFA) of the wastewater in the EGSB tank was measured by titrimetry [45]. CTC residue in the wastewater was detected by High Performance Liquid Chromatography (HPLC) analysis (Shimadzu LC-2010A, Japan) equipped with a UV absorbance detector, and the analytical method for the CTC analysis was shown in Table 3. Dissolved oxygen (DO) and temperature were monitored with DO meter (HQ 30d 53LED ${ }^{\mathrm{TM}} \mathrm{HACH}$, USA). All measurements were conducted in five replicates.

\section{Results and Discussion}

3.1. Properties of CAICF. Firstly, physical properties of CAICF as shown in Table 4 revealed that the fillers had low bulk density and grain density. The low bulk density implied abundant void, which could enhance mass transfer and prevent short-circuiting. The low grain density might improve backwashing process and SS intercepted by the fillers could be easily removed during backwashing process. Therefore, utilization of CAICF as fillers could ensure the reliability of $\mathrm{ME}$ reactor.

Secondly, Figure 2 showed the appearance and microstructure of CAICF ((a) surface, (b) fracture surface). Figure 2(a) demonstrated a few small and large apertures distributed on the rough surface of CAICF, mainly caused by the escaped gas from interior of CAICF during the sintering treatment. As mentioned in our previous study [28], the 
TABLE 3: Analytical methods for CTC analysis with a HPLC.

\begin{tabular}{lccccc}
\hline $\begin{array}{c}\text { Column } \\
\text { stationary phase }\end{array}$ & $\begin{array}{c}\text { Injection volume } \\
(\mu \mathrm{L})\end{array}$ & $\begin{array}{c}\text { Flow rate } \\
\left(\mathrm{mL} \mathrm{min}^{-1}\right)\end{array}$ & UV detection $(\mathrm{nm})$ & Eluent \\
\hline CTC & $\mathrm{C} 8^{\mathrm{b}}$ & 50 & 1.0 & 355 & $0.01 \mathrm{M}$ oxalic acid : methanol : acetonitrile $(72: 8: 20)$ \\
\hline
\end{tabular}

${ }^{\mathrm{b}}$ Luna $5 \mu \mathrm{C} 8(2) 100$ A (Phenomenex, Torrance, CA, USA): $150 \mathrm{~mm}(\mathrm{~L}) \times 4.6 \mathrm{~mm}(\phi)$.

TABLE 4: Physical properties of CAICF.

\begin{tabular}{lccc}
\hline Ceramics & Bulk density $\left(\mathrm{kg} \mathrm{m}^{-3}\right)$ & Grain density $\left(\mathrm{kg} \mathrm{m}^{-3}\right)$ & Water absorption $(\mathrm{wt} \%)$ \\
\hline CAICF & 918.5 & 1318.2 & 13.6 \\
\hline
\end{tabular}

TABLE 5: Toxic metal leaching tests of CAICF.

\begin{tabular}{lcc}
\hline Toxic metal & $\begin{array}{c}\text { Contents } \\
\left(\mathrm{mg} \mathrm{kg}^{-1} \text { of CAICF }\right)\end{array}$ & $\begin{array}{c}\text { Threshold } \\
\left(\mathrm{mg} \mathrm{kg}^{-1} \text { of hazardous }\right. \\
\text { waste })\end{array}$ \\
\hline Total $\mathrm{Cu}$ & 0.08 & 100.00 \\
Total $\mathrm{Zn}$ & 0.02 & 100.00 \\
Total $\mathrm{Cd}$ & 0.01 & 1.00 \\
Total $\mathrm{Pb}$ & 0.06 & 5.00 \\
Total $\mathrm{Cr}$ & 0.02 & 15.00 \\
Total $\mathrm{Hg}$ & - & 0.10 \\
Total $\mathrm{Ba}$ & 0.05 & 100.00 \\
Total $\mathrm{Ni}$ & - & 5.00 \\
Total $\mathrm{As}$ & 0.02 & 5.00 \\
\hline
\end{tabular}

rough surface could make fillers contact with wastewater more easily and the apertures on surface could promote the wastewater flow into the interior of CAICF, resulting in enhancement of treating effect. Figure 2(b) revealed lots of small and large apertures distributed inside of CAICF, meaning that the wastewater could flow through inside of the fillers. Consequently, the wastewater could be treated sufficiently inside of the fillers and the interior might not be easily blocked by SS. Therefore, utilization of CAICF as fillers might be satisfactory according to the microstructure analysis.

Thirdly, results of the toxic metal leaching test of CAICF were shown in Table 5, revealing that all the nine metal concentrations $(\mathrm{Cu}, \mathrm{Zn}, \mathrm{Pb}, \mathrm{Cr}, \mathrm{Cd}, \mathrm{Hg}, \mathrm{Ba}, \mathrm{Ni}$, and $\mathrm{As})$ in lixivium were much lower than the limits of the national standard (GB 5085.3-2007). The results suggested that CAICF utilized as fillers would not lead to secondary pollution to water environment. Additionally, comparing with the detection for DSS [44], all the toxic metal leaching concentrations of CAICF were far lower than those of DSS, especially for total $\mathrm{Cu}, \mathrm{Zn}, \mathrm{Cr}, \mathrm{Pb}$, and $\mathrm{Ba}$. This result showed that utilization of DSS to prepare CAICF could immobilize the toxic metals in DSS and consequently decrease the pollution of DSS.

Overall, it could be deduced that CAICF used as fillers of $\mathrm{ME}$ reactor might be feasible, safe, and reasonable according to the properties test.

\subsection{CTC Wastewater Pretreatment Effect by $M E$}

3.2.1. Initial $\mathrm{pH}$ of the Wastewater. $\mathrm{pH}$ is an important parameter for ME reaction and may affect the treatment effect of $\mathrm{ME}$ reactor. Therefore, seven $\mathrm{pH}$ values were selected to study the influence of initial $\mathrm{pH}$ on $\mathrm{ME}$ reactor. During this experiment, CAICF was applied as fillers in the ME reactor; HRT was kept at $8.0 \mathrm{~h}$ under aerating condition.

The influence of initial $\mathrm{pH}$ on CTC and CODcr removal was shown in Figure 3(a). The results revealed that the removal efficiency of CODcr and CTC decreased rapidly when initial $\mathrm{pH}$ increased from about 3.0 to 7.0 , and the removal efficiency decreased slightly as initial $\mathrm{pH}$ increased from about 1.0 to 3.0. It was likely that corrosion and dissolution of $\mathrm{Fe}^{0}$ in the fillers were more easily proceeded under acidic condition; therefore, more reducing agents $\left(\mathrm{Fe}^{0}\right.$, $\mathrm{Fe}^{2+}$, and active radical $\left.([\mathrm{H}])\right)$ could be generated, resulting in destruction and reduction of CTC in the wastewater [28, 46]. Moreover, hydroxyl radical $\left({ }^{\circ} \mathrm{OH}\right)$, as a strong oxidizing agent, might be easily generated during $\mathrm{ME}$ reactions under aerating conditions, resulting in oxidation of CTC and COD residue in the wastewater. However, when the wastewater reached neutral and alkaline condition, iron oxides and hydroxides were easily formed on the surface of the fillers, resulting in slow iron corrosion and surface passivation, consequently leading to the weakening of reduction and oxidation effect by the ME reactor. Therefore, higher CTC removal efficiency by the ME reactor was obtained on acidic condition than that on neutral and alkaline condition, and the CTC removal efficiency increased when $\mathrm{pH}$ decreased gradually, probably due to the acceleration of Fe corrosion, which could strengthen the reduction and oxidation effect by the ME reactor. However, when $\mathrm{pH}$ in the wastewater was too low, dissolution of Fe was accelerated drastically, which would greatly decrease service life of the sintered fillers. Therefore, 3.0 should be the optimum $\mathrm{pH}$ for the $\mathrm{ME}$ reactor in order to obtain high CTC removal efficiency and long service life of the sintered fillers.

3.2.2. HRT of the Wastewater. HRT is also a crucial parameter for $\mathrm{ME}$ reaction. Therefore, eight HRTs were selected to study the influence of HRT on CODcr and CTC removal of ME reactor. During this experiment, initial $\mathrm{pH}$ was kept at about 3.0 under aerating condition.

Figure 3(b) showed the influence of HRT on the removal efficiency of CODcr and CTC by ME reactor, revealing that the removal efficiency increased quickly when HRT was increased from $1.0 \mathrm{~h}$ to $4.0 \mathrm{~h}$, and it varied slightly as HRT was increased from $4.0 \mathrm{~h}$ to $8.0 \mathrm{~h}$. It could be deduced that ME reaction could not be accomplished with short HRT, which might be confirmed by abnormally low $\mathrm{pH}$ in 


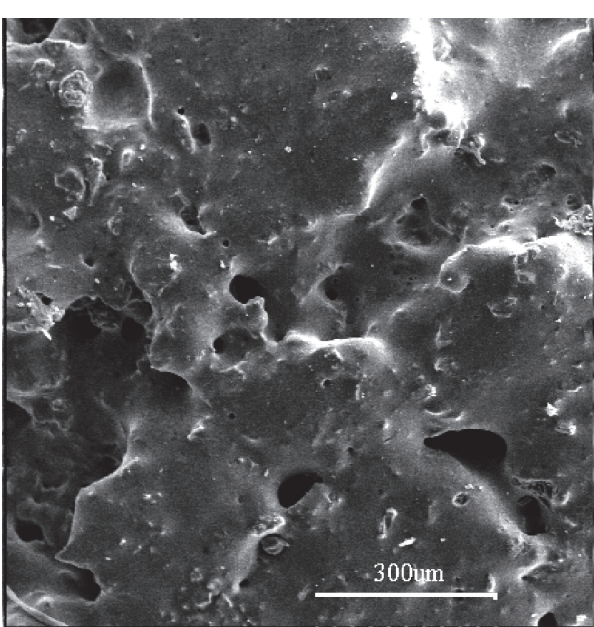

(a)

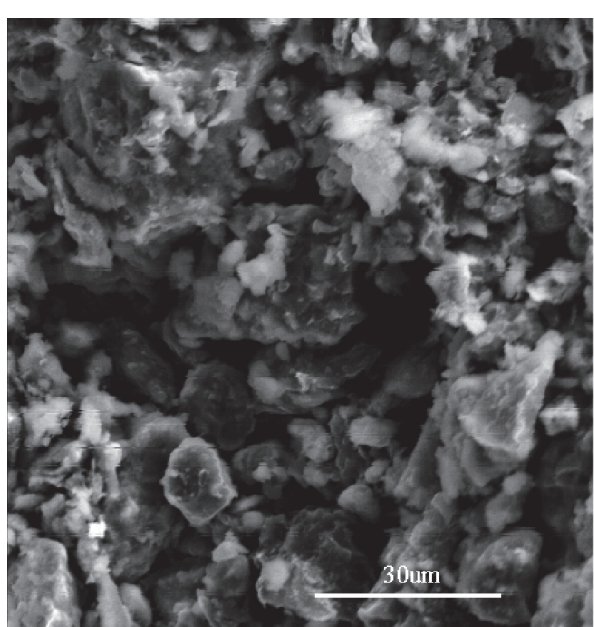

(b)

FIgURE 2: The appearance and microstructure of CAICF (SEM): (a) surface, (b) fracture surface.

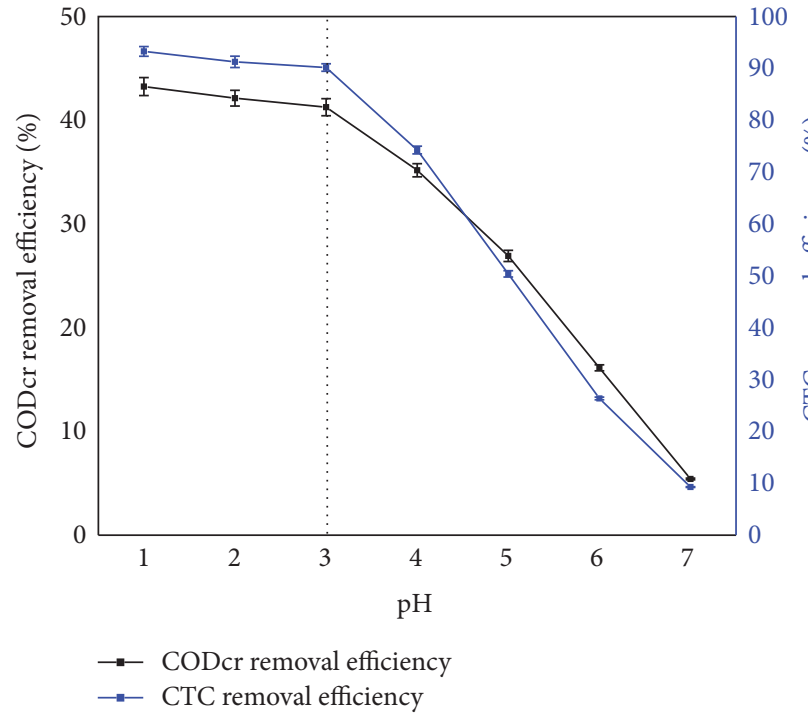

(a)

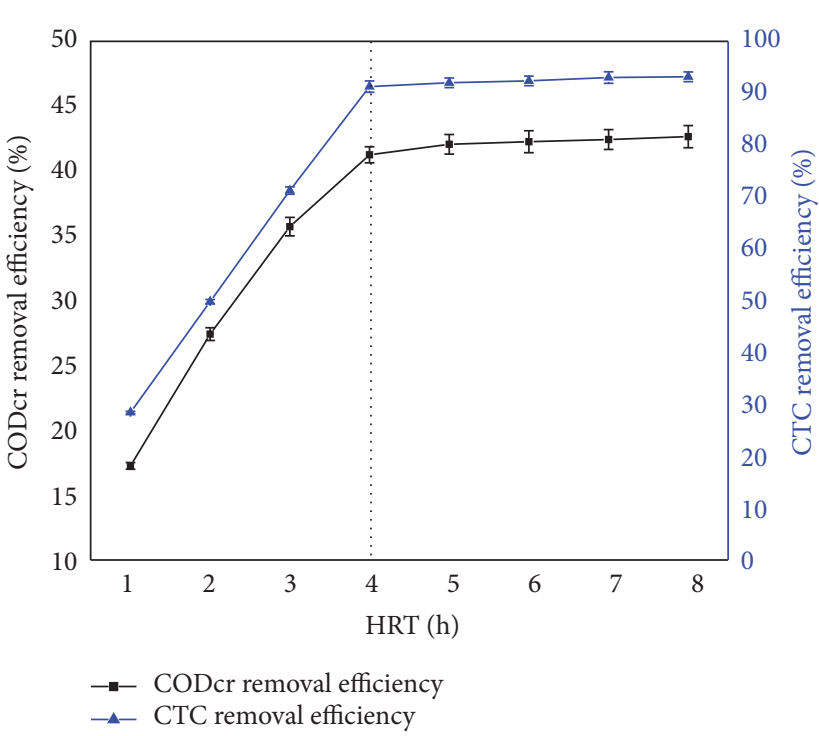

(b)

FIgURE 3: Influence of initial $\mathrm{pH}$ and HRT on ME treatment effect ((a) pH, (b) HRT).

effluent, resulting in low removal efficiency of CODcr and CTC. Consequently, the removal efficiency increased quickly when HRT was increased from $1.0 \mathrm{~h}$ to $4.0 \mathrm{~h}$. However, when HRT exceeded $4.0 \mathrm{~h}$, the reaction time was enough for accomplishing ME reaction sufficiently. Additionally, $\mathrm{pH}$ in the effluent (about 6.50) varied slightly as HRT was increased from $4.0 \mathrm{~h}$ to $8.0 \mathrm{~h}$, probably leading to the slight variation of removal efficiency. In all, the optimum HRT for the ME reactor should be $4.0 \mathrm{~h}$ determined by the CODcr and CTC removal efficiency.

3.2.3. Mechanisms for CTC and CODcr Removal. In ME reactor, several reaction mechanisms are involved in $\mathrm{ME}$ reactions for CTC removal. Firstly, the residual CTC might be reduced by the reduction effect, which was derived from active radical $([\mathrm{H}]), \mathrm{Fe}^{0}$, and $\mathrm{Fe}^{2+}$ under acidic conditions
[47]. It was known that when contacted with wastewater under acidic conditions, $\mathrm{Fe}^{0}$ could react with $\mathrm{H}^{+}$and generated active radical $([\mathrm{H}])$, which was a strong reducing agent to reduce CTC. Additionally, $\mathrm{Fe}^{0}$ and its corrosion product $\left(\mathrm{Fe}^{2+}\right)$ were also reducing agents, which could also reduce CTC. Secondly, $\mathrm{H}^{+}$was consumed during ME reactions and $\mathrm{pH}$ reached neutral and alkaline conditions gradually, resulting in the generation of iron hydroxide $\left(\mathrm{Fe}(\mathrm{OH})_{2}\right.$ and $\mathrm{Fe}(\mathrm{OH})_{3}$ ), which could remove the residual CTC and CODcr by flocculation effect $[48,49]$. Thirdly, the electrode voltage under acidic and aerating conditions $(+1.67 \mathrm{~V})$ was higher than that under acidic and anaerobic conditions $(+0.40 \mathrm{~V})$, which could enhance ME reactions and accelerate corrosion of Fe, resulting in the improvement of CTC removal [46]. Additionally, as a strong oxidizing agent, hydroxyl radical $\left({ }^{\circ} \mathrm{OH}\right)$ might be generated during ME reactions under 


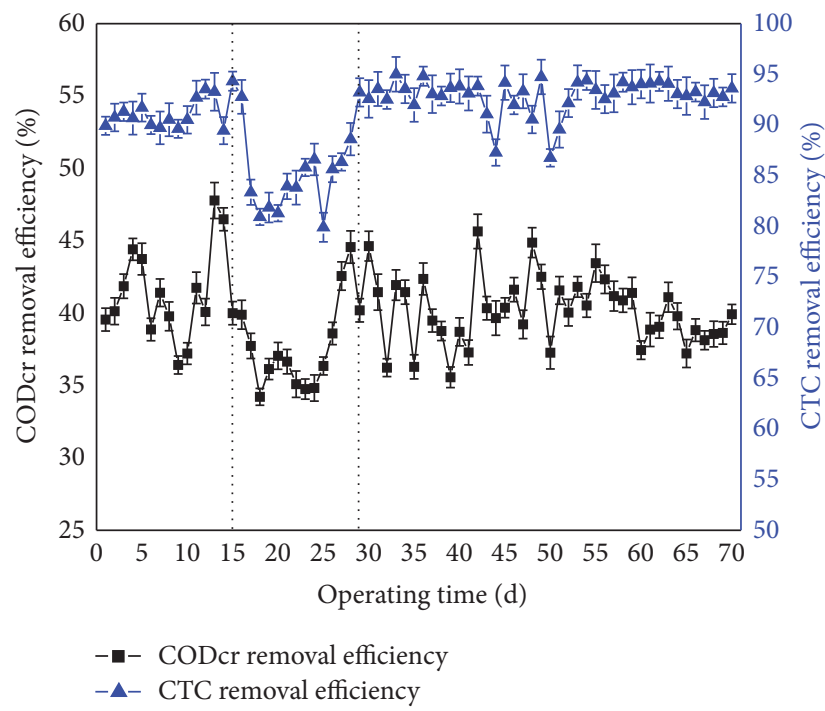

FIgURE 4: Operating effect of the ME reactor.

aerating conditions, which has been demonstrated by some researchers $[50,51] .{ }^{\circ} \mathrm{OH}$ might oxidize the residual CTC and remove some CODcr in the wastewater. Overall, CTC and CODcr in the wastewater were mainly removed by reducing, oxidizing, and flocculation effects.

3.2.4. Operating Effect of $M E$ Reactor. According to the above experiments, the optimum initial $\mathrm{pH}$ (about 3.0) and HRT $(4.0 \mathrm{~h})$ were applied in the pilot-scale experiment and the ME reactor was packed with CAICF.

Figure 4 showed the operating results of the ME reactor in the whole experiment. It could be seen that the ME reactor could get stable CODcr and CTC removal efficiency $(40.0 \%$ and $90.0 \%$, resp.). It was noted that the removal efficiency decreased appreciably (about 5.0\%) from $15 \mathrm{~d}$ to $29 \mathrm{~d}$, probably due to the blockage of the reactor by SS in the wastewater. Consequently, the mass transfer of wastewater was inhibited, resulting in the decrease of removal efficiency. After the backwash for the reactor, the removal efficiency was recovered. Therefore, the reactor was backwashed regularly (the backwashing cycle was about $15 \mathrm{~d}$ ) and the reactor operated stably during the later experiment.

From the operating effect, it could be deduced that the molecular structure of CTC might be destroyed by the ME reactor and the majority of CTC residue in the wastewater might be decomposed or inactivated, and biotoxicity of the wastewater might be decreased according to the high removal efficiency of the ME reactor and the operating effect of later biological treatment. Therefore, it could be deduced that utilization of this ME reactor for CTC wastewater pretreatment was feasible and satisfactory.

3.3. Anaerobic Biological Treatment by EGSB. After the ME pretreatment, EGSB tank was used as the following anaerobic biological treatment for the wastewater, in order to remove the majority of CODcr in the wastewater and further enhance biodegradability of the wastewater.

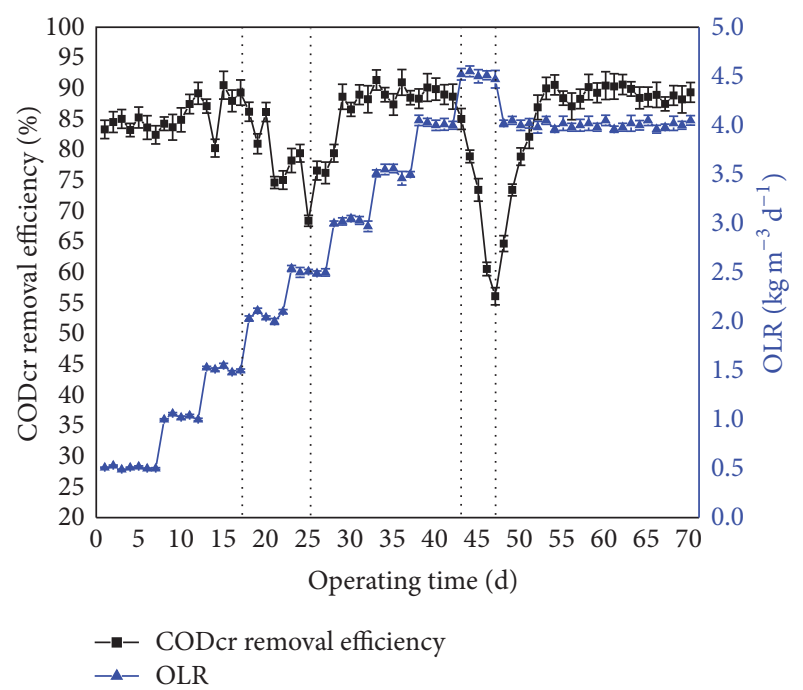

FIgure 5: The effect of EGSB tank.

CODcr removal efficiency of the EGSB tank was shown in Figure 5. The results showed that the operating effect fluctuated occasionally during the microbial acclimation stage and CODcr removal efficiency could reach $85.0 \%$ to 90.0\% after microbial acclimation was accomplished. During the whole experiment, it could be observed that CODcr removal efficiency decreased obviously on two stages. The first stage appeared from $17 \mathrm{~d}$ to $25 \mathrm{~d}$, it was likely that dominant bacteria in the EGSB tank have not been greatly reproduced, and it could not bear high OLR $\left(2.0 \mathrm{~kg} \mathrm{~m}^{-3} \mathrm{~d}^{-1}\right)$, resulting in insufficient degradation of organic substances by dominant bacteria. Meanwhile, granule sludge in the tank was recombined and some bacteria that could not adapt to the wastewater would be eliminated, resulting in the discharge of some eliminated flocculent sludge. When the tank was operated after $25 \mathrm{~d}$, the CODcr removal efficiency trended to stability, suggesting that dominant bacteria might reproduce gradually in the tank.

On the second stage ( 43 to $47 \mathrm{~d}$ ), when OLR reached about $4.5 \mathrm{~kg} \mathrm{~m}^{-3} \mathrm{~d}^{-1}$, the CODcr removal efficiency decreased rapidly with the rapid increase of VFA (from 2.59 to $\left.10.08 \mathrm{mmol} \mathrm{L}^{-1}\right)$. It was likely that the present OLR has exceeded endurance limit of dominant bacteria, resulting in insufficient degradation of organic substances. It could be deduced that CTC loading rate was enhanced as OLR increased due to small amount of CTC residue in the wastewater, resulting in the inhibition of dominant bacteria. It is well known that methane and carbon dioxide are the end-products of anaerobic biological treatment. Two groups of bacteria play the major roles in this process: acetoclastic methanogens and hydrogenotrophic methanogens; the former transform acetate to methane and carbon dioxide, and the latter can produce methane and carbon dioxide by utilizing hydrogen produced during anaerobic oxidation of soluble organics. Moreover, about $75 \%$ of the methane produced during anaerobic biological treatment is caused by the acetoclastic methanogen activity [52]. CTC could inhibit both homoacetogenic bacteria and acetoclastic methanogens, 


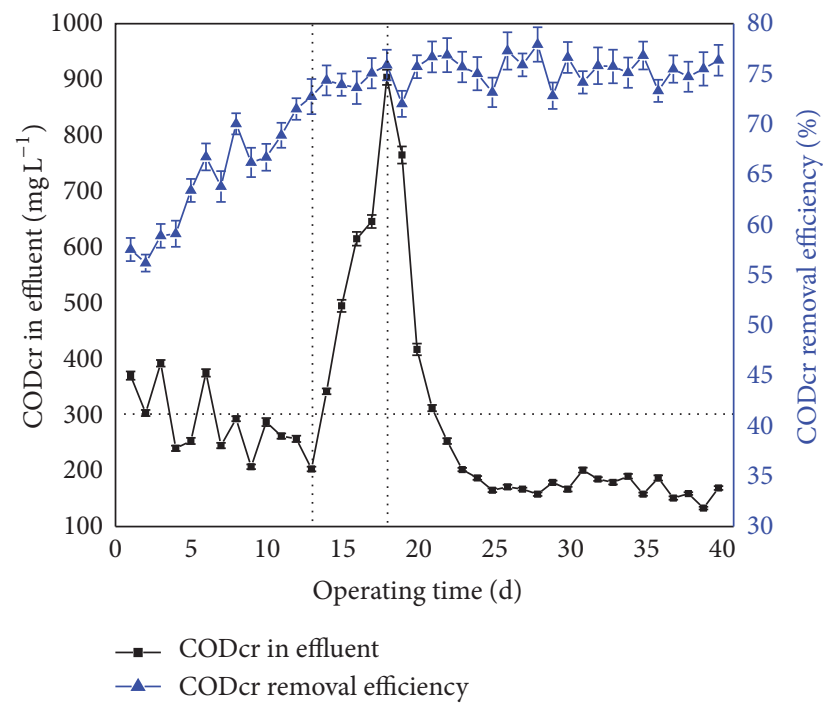

FIGURE 6: The effect of SBR reactor.

which could utilize acetate, and consequently affect methane production by these microorganisms [53]. Moreover, acetogenic bacteria could also be inhibited by CTC, resulting in accumulation of VFA in the tank. After this stage, OLR was reduced to $4.0 \mathrm{~kg} \mathrm{~m}^{-3} \mathrm{~d}^{-1}$ and the tank was recovered to normal stage gradually, resulting in the increase of the CODcr removal efficiency.

To sum up, the optimum OLR of the EGSB tank was about $4.0 \mathrm{~kg} \mathrm{~m}^{-3} \mathrm{~d}^{-1}$ with $85.0 \%$ to $90.0 \%$ of CODcr removal efficiency, and the anaerobic treatment effect demonstrated that biotoxicity of the wastewater could be reduced by the ME reactor.

3.4. Aerobic Biological Treatment by SBR. Subsequently, SBR was utilized for the aerobic biological treatment, mainly focusing on CODcr residue and majority of $\mathrm{NH}_{3}-\mathrm{N}$ removal, and SBR reactor was started after EGSB has been operated for $30 \mathrm{~d}$.

CODcr removal efficiency of SBR reactor was shown in Figure 6, revealing that the reactor could reach stable stage easily (about $23 \mathrm{~d}$ ) and it operated stably after $23 \mathrm{~d}$ with the stable CODcr removal efficiency (about 75.0\%). From 1 to $13 \mathrm{~d}$, it could be observed that CODcr in effluent was decreased gradually with the increase of CODcr removal efficiency, suggesting that quantity of aerobic heterotrophic bacteria might grow and reproduce gradually. From 13 to $18 \mathrm{~d}$, CODcr in the effluent increased rapidly, probably due to the increase of influent CODcr in SBR, mainly caused by the overload operating of EGSB tank. However, the CODcr removal was affected slightly in this stage, mainly due to the sufficient aerobic heterotrophic bacteria and effective degradation of organic substance, resulting in high CODcr removal efficiency. Meanwhile, the results suggested that the SBR reactor had strong shock resistance ability. After $18 \mathrm{~d}$, CODcr in effluent decreased gradually and subsequently trended to stability, and the reactor entered into the stable stage on $23 \mathrm{~d}$.

Overall, after the SBR reactor reached stability, about $75.0 \%$ of influent CODcr could be removed and the effluent

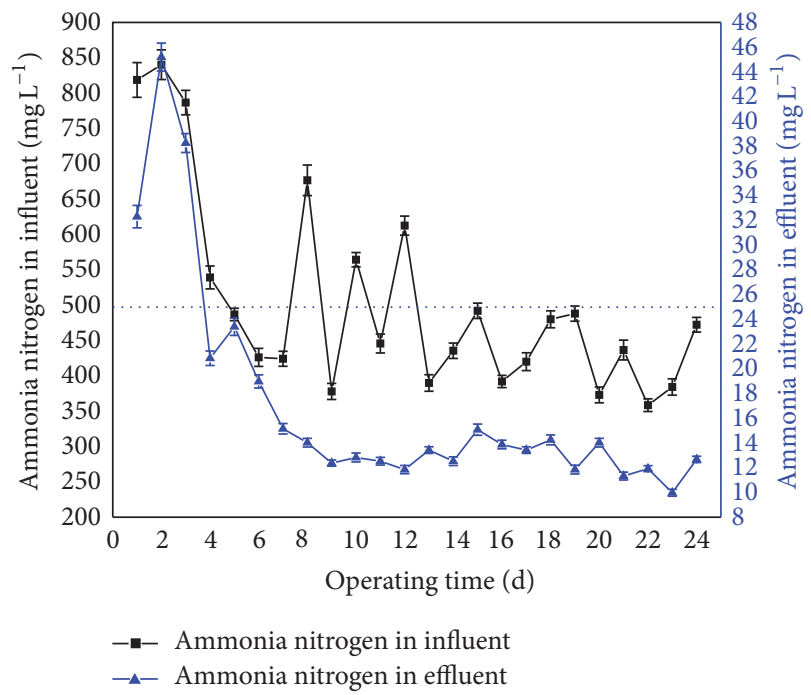

FIGURE 7: $\mathrm{NH}_{3}-\mathrm{N}$ removal effect of the system.

CODcr could be always lower than $300 \mathrm{mg} \mathrm{L}^{-1}$ on the basis of stable operation of EGSB tank. Moreover, this SBR reactor had strong shock resistance ability.

3.5. Nitrogen Removal Effect by the Whole System. $\mathrm{NH}_{3}-\mathrm{N}$ removal effect by the whole system was investigated when the SBR reactor has been operated for about $16 \mathrm{~d}$. The results were shown in Figure 7. It could be observed that the effluent $\mathrm{NH}_{3}-\mathrm{N}$ was higher in the first three days than that in later time, mainly caused by the high influent $\mathrm{NH}_{3}-\mathrm{N}$ of the system. From 1 to $7 \mathrm{~d}$, the effluent $\mathrm{NH}_{3}-\mathrm{N}$ was decreased gradually, mainly due to the growth and reproduction of nitrifying bacteria in the SBR reactor. After this stage, the system entered into the stable stage, resulting in the stable $\mathrm{NH}_{3}-\mathrm{N}$ in the effluent of the system. Additionally, $\mathrm{NH}_{3}-\mathrm{N}$ in the wastewater was mainly removed by the SBR reactor, demonstrating the great $\mathrm{NH}_{3}-\mathrm{N}$ removal ability of SBR reactor [54-56].

Finally, it could be concluded that the whole system could remove about $95.0 \%$ of $\mathrm{NH}_{3}-\mathrm{N}$ in the wastewater, and $\mathrm{NH}_{3}-\mathrm{N}$ in the final effluent of the system could be always lower than $25.0 \mathrm{mg} \mathrm{L}^{-1}$.

\section{Conclusions}

In this study, conclusions were shown as follows:

(1) Utilization of solid waste (DSS and SI) to prepare new media CAICF was feasible and satisfactory according to the physical properties, microstructure analysis, and toxic metal leaching test of CAICF.

(2) CAICF applied as filler in ME reactor for CTC wastewater pretreatment was effective, approximately $40.0 \%$ of CODcr and $90.0 \%$ of CTC residue in the wastewater were removed, and biodegradability of the raw wastewater was enhanced effectively.

(3) The coupled ME-EGSB-SBR system could treat the CTC wastewater effectively, approximately $98.0 \%$ of 
CODcr and $95.0 \%$ of $\mathrm{NH}_{3}-\mathrm{N}$ could be removed, and the final effluent met the requirement of national standard (CODcr $\left.\leq 300 \mathrm{mg} \mathrm{L}^{-1}, \mathrm{NH}_{3}-\mathrm{N} \leq 25 \mathrm{mg} \mathrm{L}^{-1}\right)$.

\section{Nomenclature}

$\begin{array}{ll}\text { CTC: } & \text { Chlortetracycline } \\ \text { OTC: } & \text { Oxytetracycline } \\ \text { DSS: } & \text { Dewatered sewage sludge } \\ \text { SI: } & \text { Scrap iron } \\ \text { CAICF: } & \text { Cathode-anode integrated ceramic filler } \\ \text { CCF: } & \text { Cathode fillers } \\ \text { ACF: } & \text { Anode fillers } \\ \text { EGSB: } & \text { Expanded granular sludge bed } \\ \text { ME: } & \text { Microelectrolysis } \\ \text { SBR: } & \text { Sequencing batch reactor } \\ \text { UASB: } & \text { Upflow anaerobic sludge blanket } \\ \text { CASS: } & \text { Cyclic activated sludge system } \\ \text { A/O: } & \text { Anoxic/oxic activated sludge process } \\ \text { SS: } & \left.\text { Suspended solid (mg } \mathrm{L}^{-1}\right) \\ \text { COD: } & \text { Chemical oxygen demand }\left(\mathrm{mg} \mathrm{L}^{-1}\right) \\ \text { NH } & \text {-N: } \\ \text { Bmmonia nitrogen }\left(\mathrm{mg} \mathrm{L}^{-1}\right) \\ \text { BOD: } & \text { Biochemical oxygen demand }\left(\mathrm{mg} \mathrm{L}^{-1}\right) \\ \text { VFA: } & \text { Volatile fatty acid }\left(\mathrm{mg} \mathrm{L}^{-1}\right) \\ \text { OLR: } & \text { Organic loading rate }\left(\mathrm{kg} \mathrm{m}^{-3} \mathrm{~d}^{-1}\right) \\ \text { HRT: } & \text { Hydraulic retention time }(\mathrm{h}) \\ \text { DO: } & \text { Dissolved oxygen }\left(\mathrm{mg} \mathrm{L}^{-1}\right)\end{array}$

\section{Competing Interests}

The authors declare that they have no competing interests.

\section{Acknowledgments}

The study was supported by Program for New Century Excellent Talents in University (NCET-11-0320); the National Natural Science Foundation of China (51378306); Shanghai Jiaotong University "Chenxing Plan (SMC-B)"; and Shandong Provincial Environmental Protection Industry Projects for Technology Research and Development (SDHBYF-201212).

\section{References}

[1] E. Neyens, J. Baeyens, M. Weemaes, and B. De Heyder, "Hot acid hydrolysis as a potential treatment of thickened sewage sludge," Journal of Hazardous Materials, vol. 98, no. 1-3, pp. 275-293, 2003.

[2] S. Werle and R. K. Wilk, "A review of methods for the thermal utilization of sewage sludge: the Polish perspective," Renewable Energy, vol. 35, no. 9, pp. 1914-1919, 2010.

[3] J. Werthera and T. Ogadab, "Sewage sludge combustion," Progress in Energy and Combustion Science, vol. 25, no. 1, pp. 55-116, 1999.

[4] S.-T. Yan, H. Zheng, A. Li et al., "Systematic analysis of biochemical performance and the microbial community of an activated sludge process using ozone-treated sludge for sludge reduction," Bioresource Technology, vol. 100, no. 21, pp. 50025009, 2009.
[5] M. R. Salsabil, J. Laurent, M. Casellas, and C. Dagot, “Technoeconomic evaluation of thermal treatment, ozonation and sonication for the reduction of wastewater biomass volume before aerobic or anaerobic digestion," Journal of Hazardous Materials, vol. 174, no. 1-3, pp. 323-333, 2010.

[6] M. Gheju and I. Balcu, "Removal of chromium from $\mathrm{Cr}(\mathrm{VI})$ polluted wastewaters by reduction with scrap iron and subsequent precipitation of resulted cations," Journal of Hazardous Materials, vol. 196, pp. 131-138, 2011.

[7] J.-H. Jiang, Y.-H. Li, and W.-M. Cai, "Experimental and mechanism research of $\mathrm{SO}_{2}$ removal by cast iron scraps in a magnetically fixed bed," Journal of Hazardous Materials, vol. 153, no. 1-2, pp. 508-513, 2008.

[8] J. R. Perey, P. C. Chiu, C.-P. Huang, and D. K. Cha, "Zero-valent iron pretreatment for enhancing the biodegradability," Water Environment Research, vol. 74, no. 3, pp. 221-225, 2002.

[9] Ö. Hanay, B. Yildiz, S. Aslan, and H. Hasar, "Removal of tetracycline and oxytetracycline by microscale zerovalent iron and formation of transformation products," Environmental Science and Pollution Research, vol. 21, no. 5, pp. 3774-3782, 2014.

[10] S. Wu, Q. Yue, Y. Qi, B. Gao, S. Han, and M. Yue, "Preparation of ultra-lightweight sludge ceramics (ULSC) and application for pharmaceutical advanced wastewater treatment in a biological aerobic filter (BAF)," Bioresource Technology, vol. 102, no. 3, pp. 2296-2300, 2011.

[11] W.-R. Chen and C.-H. Huang, "Adsorption and transformation of tetracycline antibiotics with aluminum oxide," Chemosphere, vol. 79, no. 8, pp. 779-785, 2010.

[12] Z. R. Hopkins and L. Blaney, "A novel approach to modeling the reaction kinetics of tetracycline antibiotics with aqueous ozone," Science of the Total Environment, vol. 468-469, pp. 337344, 2013.

[13] N. Kemper, "Veterinary antibiotics in the aquatic and terrestrial environment," Ecological Indicators, vol. 8, no. 1, pp. 1-13, 2008.

[14] M. Hammad Khan, H.-S. Jung, W. Lee, and J.-Y. Jung, "Chlortetracycline degradation by photocatalytic ozonation in the aqueous phase: mineralization and the effects on biodegradability," Environmental Technology, vol. 34, no. 4, pp. 495-502, 2013.

[15] I. Kim and H. Tanaka, "Photodegradation characteristics of PPCPs in water with UV treatment," Environment International, vol. 35, no. 5, pp. 793-802, 2009.

[16] R. Daghrir, P. Drogui, and M. A. El Khakani, "Photoelectrocatalytic oxidation of chlortetracycline using $\mathrm{Ti} / \mathrm{TiO}_{2}$ photo-anode with simultaneous $\mathrm{H}_{2} \mathrm{O}_{2}$ production," Electrochimica Acta, vol. 87, pp. 18-31, 2013.

[17] J. J. López-Peñalver, M. Sánchez-Polo, C. V. Gómez-Pacheco, and J. Rivera-Utrilla, "Photodegradation of tetracyclines in aqueous solution by using $\mathrm{UV}$ and $\mathrm{UV} / \mathrm{H}_{2} \mathrm{O}_{2}$ oxidation processes," Journal of Chemical Technology and Biotechnology, vol. 85, no. 10, pp. 1325-1333, 2010.

[18] J. J. López Peñalver, C. V. Gómez Pacheco, M. Sánchez Polo, and J. Rivera Utrilla, "Degradation of tetracyclines in different water matrices by advanced oxidation/reduction processes based on gamma radiation," Journal of Chemical Technology and Biotechnology, vol. 88, no. 6, pp. 1096-1108, 2013.

[19] J. Jeong, W. Song, W. J. Cooper, J. Jung, and J. Greaves, “Degradation of tetracycline antibiotics: mechanisms and kinetic studies for advanced oxidation/reduction processes," Chemosphere, vol. 78, no. 5, pp. 533-540, 2010.

[20] H. C. Zhang, W.-R. Chen, and C.-H. Huang, "Kinetic modeling of oxidation of antibacterial agents by manganese oxide," 
Environmental Science and Technology, vol. 42, no. 15, pp. 55485554, 2008.

[21] X. L. Bao, Z. M. Qiang, W. C. Ling, and J.-H. Chang, "Sonohydrothermal synthesis of $\mathrm{MFe}_{2} \mathrm{O}_{4}$ magnetic nanoparticles for adsorptive removal of tetracyclines from water," Separation and Purification Technology, vol. 117, pp. 104-110, 2013.

[22] S. E. Allaire, J. Del Castillo, and V. Juneau, "Sorption kinetics of chlortetracyline and tylosin on sandy loam and heavy clay soils," Journal of Environmental Quality, vol. 35, no. 4, pp. 969972, 2006.

[23] R. V. P. Jutta and L. David, "Sorption of tetracycline and chlortetracycline on $\mathrm{K}^{-}$and $\mathrm{Ca}^{-}$saturated soil clays, humic substances, and clay-humic complexes," Environmental Science \& Technology, vol. 41, no. 6, pp. 1928-1933, 2007.

[24] J. Rivera-Utrilla, C. V. Gómez-Pacheco, M. Sánchez-Polo, J. J. López-Peñalver, and R. Ocampo-Pérez, “Tetracycline removal from water by adsorption/bioadsorption on activated carbons and sludge-derived adsorbents," Journal of Environmental Management, vol. 131, pp. 16-24, 2013.

[25] Y. Qi, S. Wu, F. Xi et al., "Performance of a coupled microelectrolysis, anaerobic and aerobic system for oxytetracycline (OTC) production wastewater treatment," Journal of Chemical Technology \& Biotechnology, vol. 91, no. 5, pp. 1290-1298, 2016.

[26] X.-C. Ruan, M.-Y. Liu, Q.-F. Zeng, and Y.-H. Ding, "Degradation and decolorization of reactive red $\mathrm{X}-3 \mathrm{~B}$ aqueous solution by ozone integrated with internal micro-electrolysis," Separation and Purification Technology, vol. 74, no. 2, pp. 195-201, 2010.

[27] H. Cheng, W. Xu, J. Liu, H. Wang, Y. He, and G. Chen, "Pretreatment of wastewater from triazine manufacturing by coagulation, electrolysis, and internal microelectrolysis," Journal of Hazardous Materials, vol. 146, no. 1-2, pp. 385-392, 2007.

[28] S. Wu, Y. Qi, Y. Gao et al., "Preparation of ceramic-corrosioncell fillers and application for cyclohexanone industry wastewater treatment in electrobath reactor," Journal of Hazardous Materials, vol. 196, pp. 139-144, 2011.

[29] D. Ying, J. Peng, X. Xu, K. Li, Y. Wang, and J. Jia, “Treatment of mature landfill leachate by internal micro-electrolysis integrated with coagulation: a comparative study on a novel sequencing batch reactor based on zero valent iron," Journal of Hazardous Materials, vol. 229-230, pp. 426-433, 2012.

[30] I. Sirés and E. Brillas, "Remediation of water pollution caused by pharmaceutical residues based on electrochemical separation and degradation technologies: a review," Environment International, vol. 40, no. 1, pp. 212-229, 2012.

[31] J. Cheng, X. Zhu, J. Ni, and A. Borthwick, "Palm oil mill effluent treatment using a two-stage microbial fuel cells system integrated with immobilized biological aerated filters," Bioresource Technology, vol. 101, no. 8, pp. 2729-2734, 2010.

[32] H. Zhou, P. Lv, Y. Shen, J. Wang, and J. Fan, "Identification of degradation products of ionic liquids in an ultrasound assisted zero-valent iron activated carbon micro-electrolysis system and their degradation mechanism," Water Research, vol. 47, no. 10, pp. 3514-3522, 2013.

[33] W.-W. Liu, X.-Y. Tu, X.-P. Wang, F.-Q. Wang, and W. Li, "Pretreatment of coking wastewater by acid out, micro-electrolysis process with in situ electrochemical peroxidation reaction," Chemical Engineering Journal, vol. 200-202, pp. 720-728, 2012.

[34] L. Huang, G. Sun, T. Yang, B. Zhang, Y. He, and X. Wang, "A preliminary study of anaerobic treatment coupled with microelectrolysis for anthraquinone dye wastewater," Desalination, vol. 309, pp. 91-96, 2013.
[35] I. Colussi, A. Cortesi, L. D. Vedova, V. Gallo, and F. K. C. Robles, "Start-up procedures and analysis of heavy metals inhibition on methanogenic activity in EGSB reactor," Bioresource Technology, vol. 100, no. 24, pp. 6290-6294, 2009.

[36] S. Connaughton, G. Collins, and V. O'Flaherty, "Psychrophilic and mesophilic anaerobic digestion of brewery effluent: a comparative study," Water Research, vol. 40, no. 13, pp. 25032510, 2006.

[37] W.-Q. Guo, N.-Q. Ren, Z.-B. Chen et al., "Simultaneous biohydrogen production and starch wastewater treatment in an acidogenic expanded granular sludge bed reactor by mixed culture for long-term operation," International Journal of Hydrogen Energy, vol. 33, no. 24, pp. 7397-7404, 2008.

[38] A. Siggins, A.-M. Enright, and V. O'Flaherty, "Methanogenic community development in anaerobic granular bioreactors treating trichloroethylene (TCE)-contaminated wastewater at $37^{\circ} \mathrm{C}$ and $15^{\circ} \mathrm{C}$," Water Research, vol. 45 , no. 8, pp. 2452-2462, 2011.

[39] N. Garcia-Mancha, D. Puyol, V. M. Monsalvo, H. Rajhi, A. F. Mohedano, and J. J. Rodriguez, "Anaerobic treatment of wastewater from used industrial oil recovery," Journal of Chemical Technology and Biotechnology, vol. 87, no. 9, pp. 1320-1328, 2012.

[40] Y. J. Chan, M. F. Chong, C. L. Law, and D. G. Hassell, "A review on anaerobic-aerobic treatment of industrial and municipal wastewater," Chemical Engineering Journal, vol. 155, no. 1-2, pp. $1-18,2009$.

[41] S. Yi, W.-Q. Zhuang, B. Wu, S. T.-L. Tay, and J.-H. Tay, "Biodegradation of p-nitrophenol by aerobic granules in a sequencing batch reactor," Environmental Science and Technology, vol. 40, no. 7, pp. 2396-2401, 2006.

[42] N. Schwarzenbeck, J. M. Borges, and P. A. Wilderer, "Treatment of dairy effluents in an aerobic granular sludge sequencing batch reactor," Applied Microbiology and Biotechnology, vol. 66, no. 6, pp. 711-718, 2005.

[43] K.-Z. Su and H.-Q. Yu, "Formation and characterization of aerobic granules in a sequencing batch reactor treating soybeanprocessing wastewater," Environmental Science and Technology, vol. 39, no. 8, pp. 2818-2827, 2005.

[44] Y. Qi, Q. Yue, S. Han et al., "Preparation and mechanism of ultra-lightweight ceramics produced from sewage sludge," Journal of Hazardous Materials, vol. 176, no. 1-3, pp. 76-84, 2010.

[45] Y. L. He, Anaerobic Biological Treatment of Wastewater, China Light Industry Press, Beijing, China, 1998.

[46] F. Ju and Y. Hu, "Removal of EDTA-chelated copper from aqueous solution by interior microelectrolysis," Separation and Purification Technology, vol. 78, no. 1, pp. 33-41, 2011.

[47] M. Stieber, A. Putschew, and M. Jekel, "Treatment of pharmaceuticals and diagnostic agents using zero-valent ironkinetic studies and assessment of transformation products assay," Environmental Science and Technology, vol. 45, no. 11, pp. 4944-4950, 2011.

[48] J.-H. Fan and L.-M. Ma, "The pretreatment by the Fe-Cu process for enhancing biological degradability of the mixed wastewater," Journal of Hazardous Materials, vol. 164, no. 2-3, pp. 1392-1397, 2009.

[49] T. B. Hofstetter, C. G. Heijman, S. B. Haderlein, C. Holliger, and R. P. Schwarzenbach, "Complete reduction of TNT and other (poly)nitroaromatic compounds under iron-reducing subsurface conditions," Environmental Science and Technology, vol. 33, no. 9, pp. 1479-1487, 1999. 
[50] Y. Segura, F. Martínez, and J. A. Melero, "Effective pharmaceutical wastewater degradation by Fenton oxidation with zerovalent iron," Applied Catalysis B: Environmental, vol. 136-137, pp. 64-69, 2013.

[51] R. C. Martins, D. V. Lopes, M. J. Quina, and R. M. QuintaFerreira, "Treatment improvement of urban landfill leachates by Fenton-like process using ZVI," Chemical Engineering Journal, vol. 192, pp. 219-225, 2012.

[52] J. J. Stone, S. A. Clay, Z. Zhu, K. L. Wong, L. R. Porath, and G. M. Spellman, "Effect of antimicrobial compounds tylosin and chlortetracycline during batch anaerobic swine manure digestion," Water Research, vol. 43, no. 18, pp. 4740-4750, 2009.

[53] T. M. Dreher, H. V. Mott, C. D. Lupo, A. S. Oswald, S. A. Clay, and J. J. Stone, "Effects of chlortetracycline amended feed on anaerobic sequencing batch reactor performance of swine manure digestion," Bioresource Technology, vol. 125, pp. 65-74, 2012.

[54] J. Adriano, S. David, E. Jack et al., "Full-scale nitrogen removal from digester liquid with partial nitritation and anammox in one SBR," Environmental Science \& Technology, vol. 43, no. 14, pp. 5301-5306, 2009.

[55] M. K. De Kreuk, J. J. Heijnen, and M. C. M. Van Loosdrecht, "Simultaneous COD, nitrogen, and phosphate removal by aerobic granular sludge," Biotechnology and Bioengineering, vol. 90, no. 6, pp. 761-769, 2005.

[56] S. Tsuneda, T. Ohno, K. Soejima, and A. Hirata, "Simultaneous nitrogen and phosphorus removal using denitrifying phosphate-accumulating organisms in a sequencing batch reactor," Biochemical Engineering Journal, vol. 27, no. 3, pp. 191-196, 2006. 

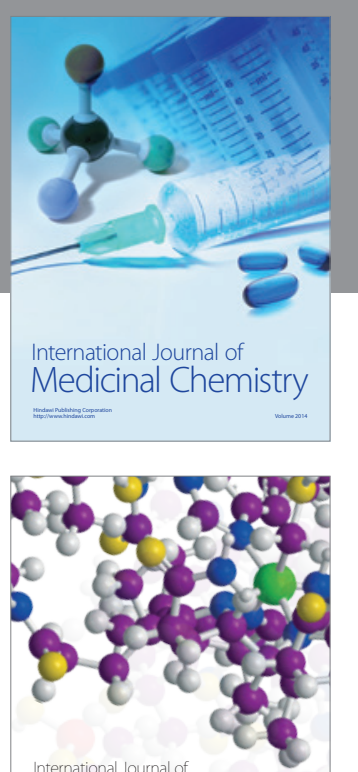

Carbohydrate Chemistry

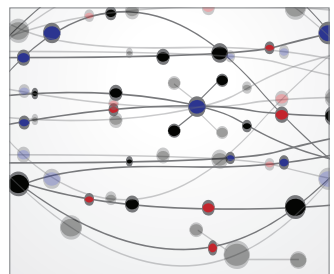

The Scientific World Journal
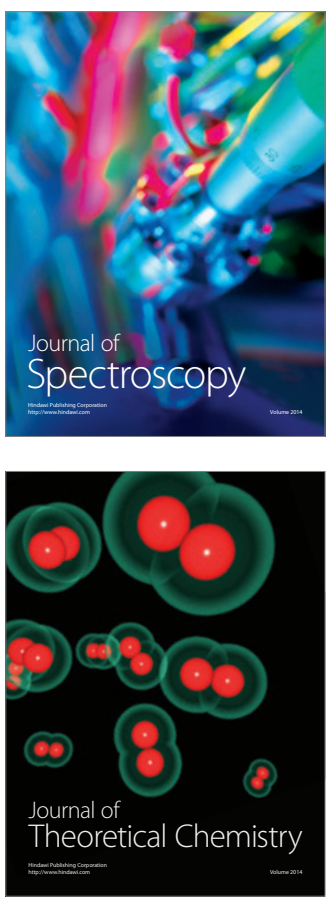
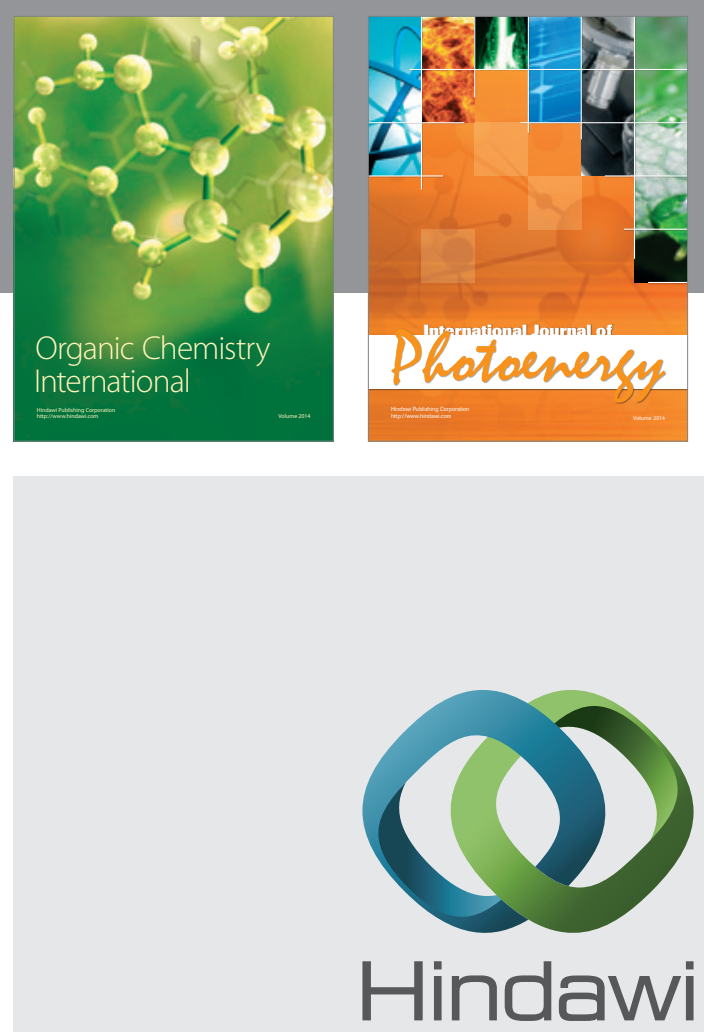

Submit your manuscripts at

http://www.hindawi.com

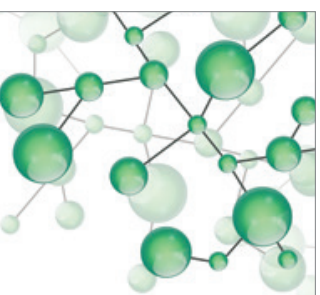

International Journal of

Inorganic Chemistry

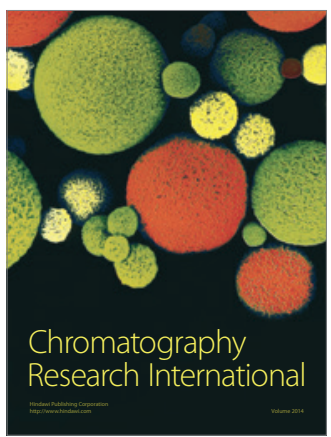

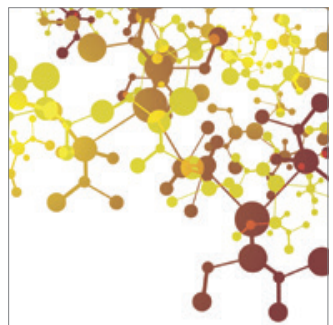

Applied Chemistry
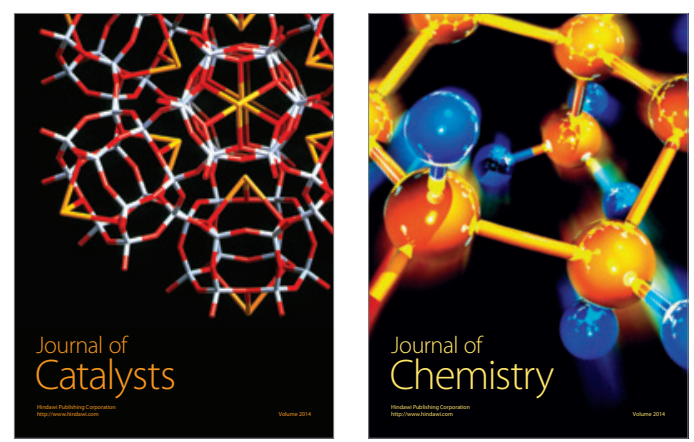
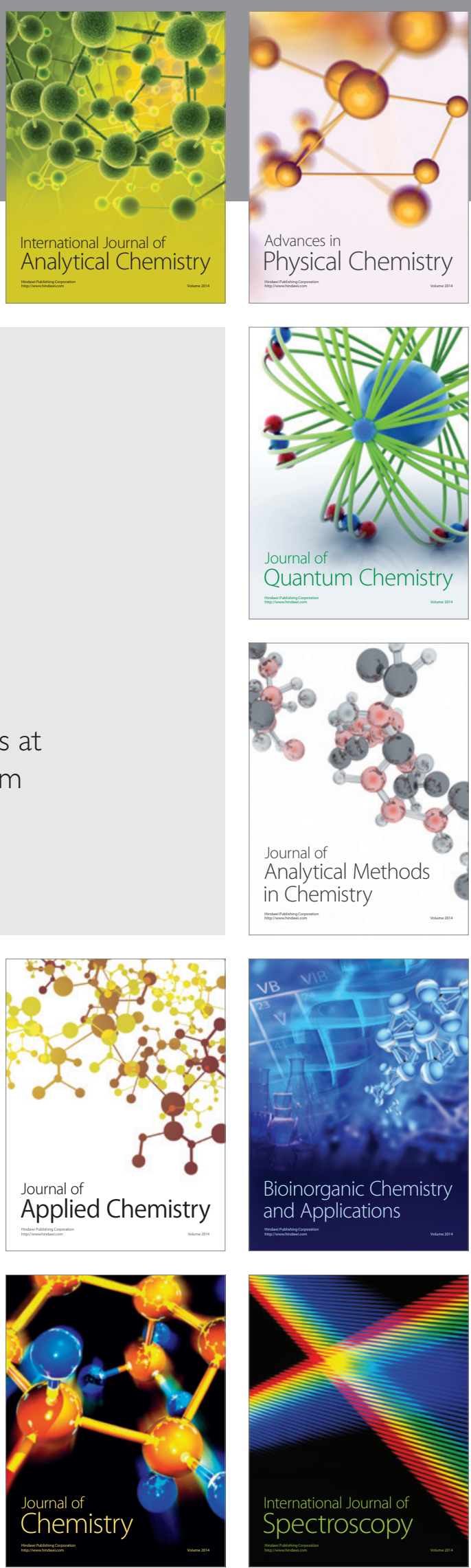